\title{
Grebneva N.N.•
}

DOI: 10.25108/2304-1730-1749.iolr.2016.46.25-47

\section{Personality of the accused as an element of proving subject on criminal case}

\begin{abstract}
Criminal prosecution and bringing of justice punishment also like a refusal from criminal prosecution of innocents, releasing them from punishment, rehabilitation of each unfoundedly subjected to criminal prosecution meets of the purposes of criminal proceedings.

Circumstances entering in subject of proving on criminal case are a certain system of ordered and interconnected elements.

Subject of proving in theory of evidences is determined like a system of the evidences expressing features and links of investigated event and are sufficient for right resolution of criminal case and tasks' realization of proceedings at law
\end{abstract}

Keywords: personality of the accused; criminal prosecution; an element of proving; system of circumstances; tasks of proceedings at law.

In compliance with article 6 of CPC (Criminal Procedure Code) of RF criminal proceedings aimed to: 1) protection of rights and legal interests of persons and organizations sustained from crime; 2) protection of person from illegal and unfounded accusation, adjudication, restriction his/her rights and freedoms.

Criminal prosecution and justice punishment of culprits meets in the same manner like refusal from criminal prosecution of innocents, release them from punishment, rehabilitation everybody who is subjected to unfounded criminal prosecution.

\footnotetext{
- Grebneva Natalya Nikolaevna - PhD in Law, Associate Professor, Chief of Department for criminal law and process of Surgut Institute of economics, management and law of Tyumen State University (Russia). Email: president@utmn.ru
} 
Studying of identity of accused is one of the elements of proving subject on each criminal case. It is impossible successfully to fulfill objectives of criminal proceedings, to determine a level of social danger and criminal punishment of an offender without clarification and analysis of information about identity of a person brought to criminal responsibility.

There is no common idea among the scientists-specialists in procedure concerning to what information about accused and which its volume should be included in proving subject $[8$, p. 14-33; 11, p. 19-21; 9, p. 31-91; 3, p. 49-64; 5, p. $23-56 ; 2$, p. $61-75 ; 24$, p. 39-53]. A characteristic of the circumstances, which are subjected to proving on criminal case including identity of accused, are contained in common kind and generalized form in the CPC of RF. According to cl. 3 p. 1 of article 73 of the CPC of RF, circumstances, which characterize identity of accused, are subjected to proving in course of production on criminal case.

Circumstances, which enter in proving subject on criminal case, present a certain system of ordered and interconnected elements. The subject of proving is presented to be a holistic formation, in which is first of all reflected the complex social phenomenon like socially dangerous deed containing the features of a crime. Internal interconnection of the elements of proving subject is determined with nature of crime and characteristic of a person committed it and is manifested in its integrity like a system: it cannot judge correctly about features of whole system if have not established its separate elements [19, p. 12].

Necessity of proving information on accused identity determined also with requirement of criminal procedure law to discover the circumstances in course of production on criminal case, which assisted of crime committing (p. 2 article 73 of the CPC of RF).

There were expressed different ideas in procedural literature on an issue of a subject of criminal procedural proving [4, p. 71-80; 23, p. 221-225; 24, p. 55-56; 20, p. 369]. 
The subject of proving is defined with the theory of evidences as a system of circumstances expressing the features and ties of investigated event, which are sufficient for correct resolution of criminal case and realization of the matters of court proceedings in each concrete case [21, p. 139].

N.M. Ignatova writes that "a subject of proving might be defined like a combination of case's circumstances, which are subjected to obligatory establishing on each criminal case, in compliance with signs of corpus delicti and requirements of criminal procedural law for correct resolution of a case" [5, p. 24].

A circle of these circumstances is wider, but any cases, the circumstances, which characterize of personality of an accused, are included here.

In context of production on cases of minors a circle of the circumstances, subjected to proving is only concretized by a lawmaker, as article 421 of the CPC of RF says nothing about establishing of any new circumstances apart those listed in article 73 of the CPC of RF.

In our opinion, analysis of article 421 of the CPC of RF comes to conclusion that there is concretized common requirements about circumstances' proving, which are contained in article 73 of the CPC of RF, and impact on level and character of responsibility of accused, circumstances characterizing an identity of accused (including age - date of birth of a minor), level of mental development and other abilities of his/her identity (par. 1, 2 of p.1 of article 421 of the CPC of RF).

This position is supported by well-known procedural scientists Yu.I. Azarov [1, p. 15-16, 66], N.S. Manova [12, p. 6, 12], V.G. Prosvirin [18, p. 126-127] and others.

Regarding to establishing of such information like the conditions of life and education of a minor, influence on the minor of elder persons (par. 2, 3 of p. 1 article 421 of the CPC of RF), we believe that they may have a character as the circumstances, which characterize an identity of accused, so the circumstances, which assist to crime committing (p. 2 of article 73 of CPC of RF). Above stated allows coming to conclusion: despite that requirements of a law about necessity of data's establishing, relating to personality of accused, are contained in various norms, these 
circumstances are between each other in close interconnection. The interconnection is concluded in that establishing of the circumstances, which characterize a personality of accused, is conducted in frames of a subject of proving on criminal case.

Circumstances, relating to personality of accused, have been included with criminal procedural legislation of a number of countries (France, Germany, Belarus, Ukraine and others) in subject of proving on criminal case. However, most of criminal procedural codes of these countries do not disclose a content of data on identity of accused.

One of the goals of studying of personality of accused is a correct solution of appearing in process of production on a case the objectives of criminal legal nature.

A person is subjected to criminal responsibility if he/she reaches sixteenth years old to time of crime commission. The persons, who reach fourteenth years old to time of crime commission, are subjected to criminal responsibility for crimes eliminated in part 2 of article 20 of Criminal Code of RF.

A person, who is not subjected to criminal responsibility, if in time of commission of socially danger deed he/she was in state of insanity, i.e. he/she could not perceive actual nature and social danger of his/her actions (inactions) or to manage with them due to chronic mental disorder, temporal mental disorder, dementia or other disease state of psyche (article 21 of Criminal Code of RF). It is not punished persons who had a mental disorder after commission of crime; this makes it impossible to assignment and execution of punishment. These persons are assigned an application of forcible measures of medical nature (p. 1 of article 97 of CPC of $\mathrm{RF})$.

In addition, information about personality of accused is an important also for correct qualification of deed in cases, when the corpus delicti contain qualifying signs, which are related to crime's subject (e.g. criminal responsibility for abuse exofficio full powers (art. 285 of Criminal Code of RF), exceeding of ex-officio full powers (art. 286 of Criminal Code of RF) are subjected only to officials). 
Consequently, non-establishing of data about person, which testify on his/her belonging to officials, might be caused a wrong qualification of deed.

Analysis of valid criminal legislation of Russian Federation allows making conclusion that circumstances, characterizing an personality of accused, are associated by the law with solution of such criminal legal matters like determination of punishment's type (articles 43, 45,47,48,49, 50, 53, 54, 55, 59 of Criminal Code of RF), common beginnings of sentencing (p. 3 of art. 60 of Criminal Code of RF), availability of circumstances mitigating (art. 61 of Criminal Code of RF) or aggravating a punishment (art. 63 of Criminal Code of RF), assignment mitigating punishment (art. 63 of Criminal Code of RF) than is provided for this crime (art. 64 of Criminal Code of RF), conditional condemnation (art. 73 of Criminal Code of RF), release from criminal responsibility (articles 75, 76, 78 of Criminal Code of RF), release from punishment (articles 80.1, 81 of Criminal Code of RF), delaying in performance of punishment to pregnant women and women who have infants (art. 82 of Criminal Code of RF) etc.

The number of matters of criminal procedural nature might be correctly resolved only under condition that there will be established necessary features of personality of accused on criminal case. First of all, they are those, which allow correct choosing a form of preliminary investigation. According to p. 1 of article 434 of CPC of RF on criminal cases in respect of persons, who committed forbidden by criminal law a deed in state of insanity or persons, to whose mental disorder were happened after crime commission, which made impossible an assignment of punishment and its execution, production of preliminary investigation is mandatory.

Besides this, under data in a case that accused is a minor or due to physical or mental handicaps cannot fulfill his/her right to defence or does not possess with language, in which is conducted production on criminal case, an investigator is obliged to provide a participation of a defender (art. 51 of CPC of RF), and in appropriate cases - an interpreter (p. 2 of art. 18 of CPC of RF), a teacher 
(psychologist) (p. 3 of art. 425 of CPC of RF), legal representative (articles 426, 437 of $\mathrm{CPC}$ of RF).

Features of personality of accused are considered under application of restraint measure in respect of him/her. As we have noted, according to art. 99 of CPC of RF, under solution of a matter on necessity of measure of restraint's application in respect of accused and determination its type there should be taken into account a seriousness of crime, information on identity of accused, his/her age, state of health, family status, kind of businesses and other circumstances. Non-establishing of enumerated circumstances during production on a case will be impeded to correct resolution a matter about choosing of measure of restraint. Yu.D. Livshits rightly noted: "It is quite understandable that there might be chosen various measures of restraint in respect of different persons, who committed the same deed" [10, p. 27].

Under CPC of RF of 1960, a decision on custody of accused was accepted by investigator or an inquiry officer, and realized only with sanction of prosecutor. According to part 3 of article 96 of CPC of RF, "under solution of a matter on sanction to arrest a prosecutor is obliged carefully to be familiarized with all materials, which substantiate taking into custody and in necessary cases to interrogate in person a suspected or accused, and with regard to a minor suspected or accused in all cases". A.S. Koblikov writes on this case, "sanctioning a decision ... on application taking in custody as measure of restraint, prosecutor has to make sure on the basis of presented him documents in reasonableness of accusation or suspicion in commission of crime by a person, in respect of whom a sanction is requested. Personal interrogation of suspected or accused by prosecutor allows him/her knowing an attitude of indicated persons to brought against them accusation or suspicion, their explanations, assisting to make correct decision on sanctioning of arrest or refuse it" [6, p. 155].

On 1 June 2002 the norms of criminal procedural legislation were conformed to the Constitution of Russian Federation, which declares (p. 2 of art. 22) that arrest, taking in custody and containing under arrest are allowed only on court decision. 
Studying of identity of accused under choosing in respect to him/her a measure of restraint as taking in custody became drawing great attention, which confirmed with decisions of Plenum of the Supreme Court of RF.

So, on the basis of decision of Plenum of the Supreme Court of RF no. 1 dated on 5 March 2004 "On application by courts the norms of Criminal procedural Code of Russian Federation" an investigator "to petition on choosing of taking in custody as measure of restraint (part 3 of article 108 of CPC of RF) should attach copies of the decisions about institution of criminal case and bringing a person as accused, copies of the reports of detention, interrogations of suspected, accused, and the evidences confirming availability of circumstances, which testify on necessity to chose taking in custody as measure of restraint (data on identity of suspected, accused, a reference about previous conviction, information about possibility to be hidden from investigation, about threats addressing to victims, witnesses etc.)" [17, p. $3]$.

In our opinion, being analyzed provisions of the norms of article 108 of CPC of $\mathrm{RF}$, we may conclude that taking in custody is extraordinary measure and should be applied only in cases, when other measures of restraint are not effective and unreasonable. This point of view is actually supported by all procedure scientists $[22$, p. $41 ; 13$, p. 159-161].

V.A. Mikhaylov writes that "taking in custody has to have extraordinary character. This means that accused person will have to be taken in custody only in those cases, when another measures of restraint cannot decide the goals, which are stipulated in article 89 of CPC of RSFSR" [15, p. 109].

“Therefore, - as it noted by E.B. Mizulina, - a judge, giving his/her consent to taking of accused in custody, has to motivate his/her decision: why one cannot be limited with softer measure of restraint" [14, p. 14].

In compliance with part 3 of article 108 of CPC of RF, an investigator in his/her decision to choose a custody as measure of restraint has to state the motives and 
grounds, which show necessity to apply taking in custody and impossibility to choose another one.

Circumstances, which assist to commission of crime, closely connected with the circumstances characterizing identity of accused person. This interconnection substantiated with the fact that successfulness their detection and elimination depends mostly on how correctly and comprehensively an investigator will be able to study an identity of accused person.

Under circumstances, which assisted to commission of crime, should be understood the circumstances mitigating an achievement or assisting to achievement of criminal result [16, p. 166]. According to V.V. Mozyakov, "under establishing the circumstances indicated should be drawn attention as to those, which were in basis of criminal behaviour (reasons), so to the circumstances, which made easy commission of crime (conditions). The circumstances, which had formed anti-social nature of person (influence of close environment) and socio-economic factors, which determined a choice of criminal behaviour, should be related to the first group. To the second group of circumstances are related a defect of accounting and protection, inactivity of prevention bodies and indifference of witnesses" [7, p. 189].

Yu.I. Azarov rightly believes that "a goal of establishing of data on identity of a person, who is brought to criminal responsibility, is necessity of his/her re-education in process of preliminary investigation" [1, p. 35].

Possessing with comprehensive data about personality of accused person, an investigator can more effective impact in those negative views of accused, which brought him/her to crime commission. But, this impact is possible only in case of establishing of psychological contact to accused person.

Comprehensive studying of identity of accused under production of pre-trial investigation allows conducting later a purposeful work on his/her re-education and correction in process of execution of punishment.

Thus, data on personality of accused is the most important element of circumstances, which are subjected to proving during investigation of crime, or by 
other words, the most significant element of subject of proving on each criminal case. And how we noted above, all elements, which enter in subject of proving, close interconnect between each other. This means that requirement of establishing any features, which characterize an identity of accused, is also provided through proving of the circumstances relating to an event of crime; guilt of accused person, form of his/her guilt and motives of crime's commission; circumstances, which testify about nature and size of damage caused by crime; circumstances, which impact to level and character of responsibility of accused person; or relating to reasons and conditions, which assisted to crime's commission.

\section{References}

1. Azarov Yu.I. Dokazyvanie sledovatelem obstoyatel'stv, kharakterizuyuschikh lichnost' obvinyaemogo [Proving by investigator of circumstances characterizing identity of accused]. Dis... kand. yurid. nauk [ PhD in Law Diss.]. Kiev, 1987, 183 p.

2. Akhmedshin R.L. Izuchenie lichnosti prestupnika $v$ metodike rassledovaniya prestupleniy [Studying personality of criminal in method of crimes' investigation]. Tomsk, 2000, $211 \mathrm{p}$.

3. Gus'kova A.P. Lichnost' obvinyaemogo v ugolovnom protsesse (problemy teorii i praktiki) [Personality of accused in criminal process (problems of theory and practice)]. Dis... dokt. yurid. nauk [Doct. Law Diss.]. Orenburg, 1997, 388 p.

4. Zinatullin Z.Z. Ugolovno-protsessual'noe dokazyvanie [Criminal procedural proving]. Uchebnoe posobie [Manual]. Izhevsk, 2003, 262 p.

5. Ignatova N.M. Izuchenie lichnosti obvinyaemogo i ispol'zovanie poluchennykh dannykh $\mathrm{v}$ khode zaschity [Studying of identity of accused by a defender and using of data received in course of defence]. Dis... kand. yurid. nauk [PhD in Law Diss.]. Izhevsk, 1997, 172 p. 
6. Kommentariy k Ugolovno-protsessual'nomu kodeksu RSFSR [Commentary to Criminal procedural Code of RSFSR]. Pod obsch. red. V.V. Mozyakova [ed. by V.V. Mozyakov]. Moscow, 2002, 864 p.

7. Korshik M.G., Stepichev S.S. Izuchenie lichnosti obvinyaemogo [Studying of identity of accused]. Moscow, 1969, 80 p.

8. Kurashvili G.K. Izuchenie sledovatelem lichnosti obvinyaemogo [Studying by an investigator identity of accused]. Moscow, 1982, 96 p.

9. Livshits Yu.D. Mery presecheniya $\mathrm{v}$ sovetskom ugolovnom protsesse [Measures of restraint in soviet criminal process]. Moscow, 1974, $130 \mathrm{p}$.

10. Lubshev Yu.F. Lichnost' obvinyaemogo [Identity of accused]. Moscow, 1985, $61 \mathrm{p}$.

11. Manova N.S. Osobennosti predmeta dokazyvaniya po delam nesovershennoletnikh [Particularities of a subject of proving on cases of minors]. Avtoref. dis... kand. yurid. nauk [PhD in Law Diss. Abstract]. Saratov, 1988, 37 p.

12. Medvedeva O.V. Ugolovnyi protsess [Criminal process]. Uchebnik/Pod red. S.A. Kolosovicha, E.A. Zaytsevoy [Textbook ed. by S.A Kolosovich, E.A. Zaytseva]. Moscow, 2003, 239 p.

13. Mizulina E. Novyi poryadok aresta i zaderzhaniya sootvetstvuyet Konstitutsii RF i mezhdunarodnym pravom standartam [New rule of arrest and detention corresponds to the Constitution of the RF and international standards]. Rossiyskaya yustitsiya [Russian Justice]. 2002, no.6. pp. 11-18.

14. Mikhaylov V.A. Ugolovno-protsessual'nye mery presecheniya v sudoproizvodstve Rossiyskoy Federatsii [Criminal procedural measures of restraint in court proceeding of Russian Federation]. Moscow, 1997, 304 p.

15. Nauchno-prakticheskiy kommentariy k Ugolovno-protsessual'nomu kodeksu Rossiiskoy Federatsii / Pod obsch.red. V.M. Lebedeva [Sci. Pract. Commentary to Code of Criminal Procedure of Russian Federation, ed. by V.M. Lebedev]. Moscow, 2004, 851 p. 
16. Postanovlenie Plenuma Verkhovnogo Suda RF no. 1 ot 5 marta 2004 g. "O primenenii sudami norm Ugolovno-protsessual'nogo kodeksa Rossiyskoy Federatsii" [Decision of the Plenum of the Supreme Court of RF no 1 of 5 March 2004 'On application by the courts the norms of the Code of Criminal Procedure of Russian Federation']. Bulleten' Verkhovnogo Suda RF [Bulletin of Supreme Court of RF]. 2004, no. 25.

17. Prosvirin V.G. Osobennosti predmeta dokazyvaniya po ugolovnym delam nesovershennoletnikh [Particularities of proving subject on criminal cases of minors]. Dis... kand. yurid. nauk [PhD in Law Diss.]. Voronezh, 2001, 214 p.

18. Stovpovoy A.G. Obstoyatel'stva kharakterizuyuschie lichnost' obvinyaemogo kak element predmeta dokazyvaniya [Circumstances characterizing of identity of accused as an element of proving subject]. Avtoref. dis... kand. yurid. nauk $[\mathrm{PhD}$ in Law Diss. Abstract]. Leningrad, 1980, 34 p.

19. Strogovich M.S. Kurs sovetskogo ugolovnogo protsessa [Course of soviet criminal process]. Moscow, 1968, vol. 1, 470 p.

20. Teoriya dokazatel'stv $\mathrm{v}$ sovetskom ugolovnom protsesse. Pod red. N.V. Zhogina [Theory of evidences in soviet criminal process, ed. by Zhogin N.V.]. Moscow, 1973, 736 p.

21. Trunov I.L., Trunova L.K. Mery presecheniya $\mathrm{v}$ ugolovnom protsesse [Measures of restraint in criminal process. S. Petersburg, 2003, 356 p.

22. Ugolovno-protsessual'noe pravo Rossiiskoy Federatsii [Criminal procedural law]. Uchebnik/Otv.red. P.A. Lupinskaya [Textbook ed. by P.A. Lupinskaya]. Moscow, 2004, 589 p.

23. Florya E. Lichnost' prestupnika [Identity of criminal]. Dis... kand. yurid. nauk [PhD in Law Diss.]. Kishinev, 2002, 188 p.

24. Shekshueva O.N. Nekotorye aspekty teorii dokazatel'stv v ugolovnom protsesse [Some aspects of theory evidences in criminal process]. Uchebnoe posobie [Manual]. Moscow, 2001, 241 p. 